\title{
Assessing the Factors Affecting Workers Commitment in Hotel Industry in the Bolgatanga Municipality of Ghana
}

\author{
John Adanse ${ }^{1}$, Leticia Touh Yamga ${ }^{2}$, Christina Abi Atinga ${ }^{3}$ \\ ${ }^{1,2,3}$ Department of Hospitality Management, Bolgatanga Polytechnic, Bolgatanga, \\ Upper East Region, Ghana
}

\begin{abstract}
This research work assesses the factors that influence organisational commitment among workers in the hotel industry, a case study of selected hotels in Bolgatanga municipal. The main objective was to assess the factors influencing organisational commitment among workers in the hotel industry. The researcher adopted the purposive sampling method to choose fifty (50) respondents from five selected hotels (Ex-Tee Hotel, Tap Hotel, Premier Lodge Hotel, Blue Sky Hotel and Black Star Hotel) in Bolgatanga Municipality. The study revealed that work and demographic characteristics have an effect on different dimensions of organisational commitment. It was recommended that management in the hotel industry should encourage employees to build optimistic attitude in their personality which would automatically increase their commitment. Also, the working environment and having the right tools should be the concern of hotel managers. It was recommended that the gender and educational level of the workers in the hotel industry be of great concern to the hotels since this has an impact on workers turnover and overall commitment.
\end{abstract}

Keywords: organisational commitment, hotel industry, Management, Employees, Ex-Tee Hotel.

\section{INTRODUCTION}

Organizational commitment has become a world-wide concept among researchers of organisational and psychological industry. This theory is an emotional concept that has been described and has been working for more than years ${ }^{[1]},{ }^{[2]}$. Industries depend on the efforts of their workers to ensure that the organization is competitive by being able to respond, adapt or change to keep pace with rapid technological advancements, education advancements, workforce diversity, organizational restructuring and the new ways of doing business. Therefore, organizational commitment is an important issue in today's highly competitive business environment ${ }^{[3]}$.

${ }^{[4]}$ Described organizational commitment as a state of psychology that characterizes the employee's relationship with the organization with its effect on the decision to continue affiliation to the organisation or not. Organizational commitment is the point at which an employee identifies his or herself with an organization and wants to continue working actively in it ${ }^{[5]}$. Employees used to be committed to an organization when they feel that their jobs were secure. However, some factors which many organizations recently have adopted such as downsizing, outsourcing, short-term contracts, job insecurity, have affected negatively to employees loyalty to their organization ${ }^{[6]}$. The services employed in the hotel and hospitality industry is mainly labour intensive and the most important component is the worker, who make available his or her the service to the organization. The success of every organization depends on the quality of personnel available to organization ${ }^{[7]}$.

Most workers in the hotel and hospitality industry are committed to the work they do. In some cases, the amount of money they have been paid for is not sufficient or the working environment is not favourable. In addition, hotel workers are being faced with factors such as problems from home, coworkers, management staff or the economy in general. It is therefore important that the factors that influence the behaviour of hotel workers should be assessed, because these factors can either make a hotel to function properly or not.

The concept of demographic factors, work experience and psychological factors on organizational commitment are studied widely in public and private sector organizations in other parts of the world, such cannot be said same in Ghana, especially the northern part of the country. 
Commitment is a multi-facet theory which is somewhat difficult to explain. Much research has been done about this concept in the fields of management, organizational behavior and human resource management. Most researchers explained organizational commitment with regards to their own their backgrounds and personal experiences ${ }^{[8][9]}$.

Organisational commitment has been conceptualized the perspectives of behaviour and psychology. The behavioural approach of organizational commitment is the interaction between employers and workers about rewards. On the other hand, the psychological perspective considered organizational commitment to be affiliation to an individual employee job ${ }^{[10]} .^{[11]}$ however stated that the major drive of organizational commitment is a psychological state that reflects a high sense of belonging, acceptance, identity, loyalty, support, passion and pride feelings towards an organization.

${ }^{[12]}$ Emphasized that age is related to commitment in a way that employees who are old in the organization would be more loyal as compare to employees who are still young in an organization. ${ }^{[5]}$ found out that older workers are more committed to an organization than the younger ones. This is because the old people at workplace will lower their expectations to a level that is more realistic. Also, employees who last long in organizations sometimes have stronger investment and greater history with the organization than the young ones and they tend to be more committed than the young workers.

Gender has a high impact on employees' organizational commitment. It is refers to as sociopsychological categories of masculinity and femininity ${ }^{[7]},{ }^{[13]}$ research revealed that women are more committed to their organizations as compare to their men counterparts. This is because; there is often discrimination against women when it comes to work issues, thereby making them to be more committed to their work.

Marital status is another demographic factor, which influences commitment. Current literature shows that married people are more committed than single people. This is because they need a sure job to take care of their families ${ }^{[14]}$. It is clear that this commitment comes from concern for the economic safety of their families. ${ }^{[15]}$ Sampled 317 staff members from 61 facilities and found that employees who were married reported higher levels of organizational commitment as compare to those who were still singles.

Education is another demographic factor which can influence organizational commitment in a way that people with lower educational level and qualification are more committed to their organizations, as they rarely change their jobs ${ }^{[15]}$.

${ }^{[16]}$ Stated that the psychological theory in knowledge and skills advancement and frequent flow of information are signals of long-term commitment from management to the organization. According to Ayesha et al (2014), working condition, pay, promotion, safety and security of the job are strongly associated with employee satisfaction which will make an employee more committed to an organisation.

\section{RESEARCH DESIGN AND METHODOLOGY}

This researcher used qualitative technique of data collection to maximally capture the opinions, feelings, and experiences of respondents about the factors affecting their commitment in their respective organisations. Bolgatanga municipal was the place for the study. The municipality had a total population of about 131,550 according to the 2010 population and housing census. Also, municipality has a total of thirty-six (36) hotels and guest houses, three (3) restaurants and 90 drinking and chops bars ${ }^{[17]}$.

The population was all the management, chefs, and waiters/waitress, gardeners, and security personnel of the selected hotels. Sample sizes of Fifty (50) respondents were used; where ten respondents were from each of the five hotels selected (Ex-Tee Hotel, Tap Hotel, Premier Lodge Hotel, Blue Sky Hotel and Black Star Hotel). Purposive sampling method was used to ensure that the desired sample was selected. Purposive sampling method was appropriate because, since the population comprised individuals from the same field of study, it was ideal to ask individuals before 
giving questionnaires out for completion. The main instrument of data collection used was the questionnaire. The data gathered on the questionnaires designed was put into Microsoft excel 2007 and Statistical Package for Social Sciences (SPSS) version 16.0 to bring out information for analysis and discussion.

\subsection{Profile of the Study Areas}

\subsubsection{Ex-tee Crystal Hotel}

Extee Crystal Hotel rates itself as the business class hotel in the Upper East. It is probably the top choice of travellers in the region now. All the rooms are neatly decorated in a fashionable style with all facilities like Restaurant, TV, Wireless internet connection, Backup generator and First aid. Visitors will be completely immersed in a lively hotel of choice, where you will have all the services at your door step. The staff of the hotel are very courteous, customer caring and will definitely make guest stay enjoyable and worth repeating.

\subsubsection{TAP Hotel}

TAP Hotel seeks to be recognized as providers of contemporary services in the hospitality industry to meet the ever-changing needs of today's workers. At TAP Hotel, they provide quality service ahead of our competitors through our knowledgeable and well-motivated staff. Searching for excellence is their passion whilst doffing of their hats to workers. Their services range from accommodation to meals and drinks. The kind and level of services to be rendered will depend on the position of the Hotel in terms of its ability to provide the service and the relationship that exists between the two parties.

\subsubsection{Premier Lodge Hotel}

Premier Lodge is situated in Bolgatanga, colloquially known as Bolga, is a town and the capital of the Bolgatanga Municipal District and Upper East Region of North Ghana. The hotel has 24-electricity and 24-hour room service. On-site parking and parking nearby are available. The rooms are spacious and clean. All rooms provide an air conditioning and fridge. Also a Flat screen TV with cable TV service is available in the room. All rooms have en-suite bathrooms with shower, bath and toiletries.

\subsubsection{Blue Sky Hotel}

Blue Sky Hotel offers all the services and sophistication that is expected of a top class hotel including but not limited to the following:

- Modern and comfortable hotel accommodation

- Conference Hall fitted with state of the art audio-visual gadgets

- Swimming Pool

- State of the art Gym, Fitness Canter

- Rooftop Bar

- Dining and Restaurant

- Internet and Wi-Fi

Blue Sky Hotel pride itself as the number one choice at any given time of the year, to have a relaxing holiday, to enjoy a romantic break, to hold a business meeting, to unwind after accumulated stress, to take a shot at the best conditions of privacy and tranquility and to recoup the well-being and energy required to move on with life.

\subsubsection{Black Star Hotel}

Black Star Hotel is located in Bolgatanga, Ghana. The hotel is rated a one-star hotel property and is located along the road in the Bolgatanga main street. The hotel offers primary product such as accommodation and food and beverages to enhance guest comfortability. 


\section{RESULTS AND DISCUSSIONS}

\section{Gender Distribution of Respondents}

In the study, males and females working in the various hotels in Bolgatanga Municipality responded to the questionnaires. Figure 1 presents the results.

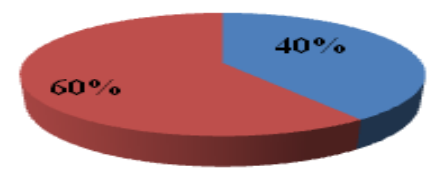

Source: Field Survey, 2017

Figure1. Gender of Respondents

From Figure1, the data revealed that $40 \%$ of the total respondents were males while $60 \%$ were females. This showed that majority of the respondents used in the study were females which is in line with the national gender population distribution of Ghana where female dominates. Also, more women seem to be engaged in the hospitality industry than men.

Table1: Age of Respondents

\begin{tabular}{|c|c|c|}
\hline Age & Number of Respondents & Percent \\
\hline $18-25$ years & 9 & 18.0 \\
\hline $26-30$ years & 18 & 36.0 \\
\hline $31-35$ years & 17 & 34.0 \\
\hline $36-40$ years & 2 & 4.0 \\
\hline $41-45$ years & 1 & 2.0 \\
\hline 51 years and above & 3 & 6.0 \\
\hline Total & $\mathbf{5 0}$ & $\mathbf{1 0 0 . 0}$ \\
\hline
\end{tabular}

Source: Field Survey, 2017

From Table 1; nine respondents representing 18\% fall 18-25 years. The modal age group of the respondents were between $26-30$ years of $36 \%$ representation. 17 respondents representing $34 \%$ were in the age group of 31-35 years. Those that were between $36-40$ years represent $4 \%$ of the respondents. One respondent representing $2 \%$ fall between $41-45$ years. Those who were above 51 years were three representing $6 \%$. The age distribution of the workers was good for the hotels since majority of the sampled respondents are young adults. However, this may have an effect on their commitment level if not checked, because some might be having higher ambitions.

\section{Name of Hotel}

The researcher sampled five hotels in Bolgatanga municipality for the research, and the details of the hotels are presented in Table 2. It is clearly shown that the researcher equitably conducted the research among the five hotels were 10 respondents each from each hotel was contacted for the research.

Table2. Name of Hotel

\begin{tabular}{|c|c|c|}
\hline Name of Hotel & Number of Respondents & Percent \\
\hline Ex-Tee Hotel & 10 & 20.0 \\
\hline Tap Hotel & 10 & 20.0 \\
\hline Premier Lodge Hotel & 10 & 20.0 \\
\hline Sun Gardens & 10 & 20.0 \\
\hline Black Star Hotel & 10 & 20.0 \\
\hline Total & $\mathbf{5 0}$ & $\mathbf{1 0 0 . 0}$ \\
\hline
\end{tabular}

Source: Field Survey, 2017

\section{Position in the Hotel}

The positions of the hotel workers who responded to the questionnaires are showed in Table 3.

The results showed that the sample consisted of individuals who were chefs, Waiter/Waitress, Receptionists, Room Attendants, Accountants, Managers, Security and others. From the analysis, $30 \%$ of the respondents representing the majority of participants have other duties. This was followed 

of Ghana

by Room Attendant representing 18\%, Managers represents 12\%, Receptionist and Security who constituted $16 \%$ each of the respondents. The rest of the respondents were chefs of the Hotel who formed $8 \%$ of the respondents while $6 \%$ were Waiter/Waitress and Accountants represent $6 \%$.

Table3. Position in the Hotel

\begin{tabular}{|c|c|c|}
\hline Position & Number of Respondents & Percent \\
\hline Chef & 4 & 8.0 \\
\hline Waiter/Waitress & 3 & 6.0 \\
\hline Receptionists & 5 & 10.0 \\
\hline Room Attendants & 9 & 18.0 \\
\hline Accountant & 3 & 6.0 \\
\hline Managers & 6 & 12.0 \\
\hline Security & 5 & 10.0 \\
\hline Other & 15 & 30.0 \\
\hline Total & $\mathbf{5 0}$ & $\mathbf{1 0 0 . 0}$ \\
\hline
\end{tabular}

Source: Field Survey march, 2017

\section{Monthly Income}

In the study, there are various levels of income among workers in the Hotels who responded to the items. The finding of the information gathered from the respondents in relation to their income levels is shown in Table 4.

In Table 4 , the data revealed that 12 respondents representing $24 \%$ were earning income between GHC100 to 200, while 14 respondents representing 28\% were earning between GHC200 to GHC300, 11 respondents representing 22\% were earning between GHC301 to GHC400, eight respondents representing 16\% were earning between GHC401 to GHC500 and for those who earns above GHC501 represents $10 \%$ of the respondents. The result indicates that most workers in hotels in Bolgatanga municipality have an income level either below or within the current daily minimum wage of GHC 8.80.

Table4. Monthly Income

\begin{tabular}{|c|c|c|}
\hline Monthly Income & Number of Respondents & Percent \\
\hline GHC100-200 & 12 & 24.0 \\
\hline GHC201-300 & 14 & 28.0 \\
\hline GHC301- 400 & 11 & 22.0 \\
\hline GHC401- 500 & 8 & 16.0 \\
\hline GHC501 and above & 5 & 10.0 \\
\hline Total & $\mathbf{5 0}$ & $\mathbf{1 0 0 . 0}$ \\
\hline
\end{tabular}

\section{Number of Working Hours}

The number of working hours of hotel workers is the required number of hour's worker are to spend in the workplace. The result is showed in Table 5. The research found out that four respondents representing $8 \%$ work between 1 to 3 hours, while 10 respondents representing $20 \%$ worked for a period between 4 to 6 hours, 13 respondents representing $26 \%$ had 11 and above hours while 23 respondents representing $46 \%$ worked seven to 10 hours. The result indicates that, majority of the respondents have worked 7-10 hours which in line with public service requirements of every employee.

Table5. Number of Working hours

\begin{tabular}{|c|c|c|}
\hline Working hours & Number of Respondents & Percent \\
\hline 1-3 hours & 4 & 8.0 \\
\hline 4-6 hours & 10 & 20.0 \\
\hline 7- 10 hours & 23 & 46.0 \\
\hline 11 hours and above & 13 & 26.0 \\
\hline Total & $\mathbf{5 0}$ & $\mathbf{1 0 0 . 0}$ \\
\hline
\end{tabular}

Source: Field Survey, 2017

\subsection{Factors That Affect Workers Commitment in the Hotel and Hospitality Industry}

This section of the research was to find the factors that affect workers commitment in the hotel industry. The factors were in two fold; work related factors and demographic factors. The respondents 
were required to use a five-liked scale; strongly agree, agree, neutral, disagree and strongly disagree to indicate their level of agreement with factors. The result is shown in Table 6 .

Table6. Factors That Affect Workers Commitment in the Hotel Industry

\begin{tabular}{|l|l|l|l|l|l|}
\hline Work-related factors & SA & A & N & D & SD \\
\hline Right tools at work place & $15(30.0 \%)$ & $12(24.0 \%)$ & $5(10.0 \%)$ & $10(20.0 \%)$ & $8(16.0 \%)$ \\
\hline Period of receiving salary & $12(24.0 \%)$ & $14(28.0 \%)$ & $2(4.0 \%)$ & $10(20.0 \%)$ & $12(24.0 \%)$ \\
\hline Work relationship with Supervisor & $9(18.0 \%)$ & $12(24.0 \%)$ & $8(16.0 \%)$ & $8(16.0 \%)$ & $13(26.0 \%)$ \\
\hline Relationship with co-workers & $6(12.0 \%)$ & $8(16.0 \%)$ & $6(12.0 \%)$ & $15(30.0 \%)$ & $15(30.0 \%)$ \\
\hline Working conditions & $12(24.0 \%)$ & $8(16.0 \%)$ & $9(18.0 \%)$ & $9(18.0 \%)$ & $12(24.0 \%)$ \\
\hline Working environment & $16(32.0 \%)$ & $14(28.0 \%)$ & $11(22.0 \%)$ & $9(18.0 \%)$ & $0(0.0 \%)$ \\
\hline Demographic factors & & & & & \\
\hline Gender & $16(32.0 \%)$ & $14(28.0 \%)$ & $11(22.0 \%)$ & $9(18.0 \%)$ & $0(0.0 \%)$ \\
\hline Age & $15(30.0 \%)$ & $12(24.0 \%)$ & $5(10.0 \%)$ & $10(20.0 \%)$ & $8(16.0 \%)$ \\
\hline Educational level & $20(40.0 \%)$ & $15(30.0 \%)$ & $6(12.0 \%)$ & $9(18.0 \%)$ & $0(0.0 \%)$ \\
\hline Marital status & $6(12.0 \%)$ & $8(16.0 \%)$ & $6(12.0 \%)$ & $15(30.0 \%)$ & $15(30.0 \%)$ \\
\hline Religion & $9(18.0 \%)$ & $12(24.0 \%)$ & $8(16.0 \%)$ & $8(16.0 \%)$ & $13(26.0 \%)$ \\
\hline
\end{tabular}

Source: Field Survey, 2017

\subsection{Work-Related Factors}

From table 6,15 respondents representing 30\% strongly agree having the right tools at work place is a factor to organizational commitment, 12 respondents representing 24\% agree, 10 respondents representing $20 \%$ disagree, five respondents representing $10 \%$ were neutral while eight respondents $16 \%$ representing strongly disagree.

Table 6 shows that 12 respondents representing 24\% strongly agree that the period of receiving salary as a factor to organizational commitment, 14 respondents representing $28 \%$ agree, two respondents representing $4 \%$ were neutral. However, 10 respondents representing $20 \%$ disagree while 12 respondents representing $24 \%$ strongly disagree.

On work relationship with Supervisor as a factor to organizational commitment, nine respondents representing $18 \%$ strongly agree, 12 respondents with $24 \%$ representation agree while eight respondents representing 16\% disagree. Also, eight respondents representing $16 \%$ were neutral while 13 respondents representing $26 \%$ strongly disagree.

Table 6 again revealed that six respondents representing 12\% strongly agree that the relationship with co-workers that exist in organization was a factor to commitment, eight respondents representing $16 \%$ agree, six respondents representing $12 \%$ were neutral while 15 respondent representing $30 \%$ of the respondents each disagreeing and strongly disagreeing.

Analysis from the findings reveal that 12 respondent representing $24 \%$ strongly agree that working conditions is another factor to organizational commitment while eight respondents representing $16 \%$ agree, and nine respondents representing $18 \%$ neutral. On the other hand, nine respondents representing $18 \%$ and 12 respondents representing $24 \%$ disagree and strongly disagree respectively.

Finally, from the Table, 16 respondents representing $32 \%$ strongly agree that working environment is a factor to organizational commitment, 14 respondents representing $28 \%$ agree, nine respondents representing $18 \%$ disagree, while 11 respondents representing $22 \%$ were neutral.

\subsection{Demographic Factors}

Table 6 shows that 16 respondents representing 32\% strongly agree that gender is a factor to organizational commitment, 14 respondents representing $28 \%$ agree, 11 respondents representing $22 \%$ were neutral, and nine respondents representing 18\% disagree. Also, 15 respondents representing $30 \%$ strongly agree that age is a factor to organizational commitment, 12 respondents representing $24 \%$ agree, five respondents representing $10 \%$ were neutral, 10 respondents representing $20 \%$ disagree, while eight respondents representing $16 \%$ strongly disagree.

With educational level as a factor to organizational commitment, the analysis show that 20 respondents representing $40 \%$ strongly agree, 15 respondents representing $30 \%$ agree, six respondents representing $12 \%$ were neutral, nine respondents representing $18 \%$ disagree while no respondents strongly disagree. Table 6 further shows that six respondents representing $12 \%$ strongly agree that marital status is an important factor to organizational commitment, eight respondents representing 
$16 \%$ agree, while six respondents representing $12 \%$ were neutral. 15 respondents representing $30 \%$ disagree while 15 respondents representing $30 \%$ strongly disagree.

The table shows that nine respondents representing $18 \%$ strongly agree that religion status of a worker is a factor to organizational commitment, 12 respondents representing $24 \%$ agree, eight respondents representing 16\% were neutral, eight respondents representing $16 \%$ disagree, while 13 respondents representing $26 \%$ strongly disagree.

\subsection{Relationship between Factors and Organizational Commitment}

The respondents were required to use a five-liked scale; strongly agree, agree, neutral, disagree and strongly disagree to indicate their level of agreement with such a relationship. The result is shown in Table 7.

From Table 7, 16 respondents representing 32\% strongly agree having the right tools at work place makes them complete their work on time, 14 respondents representing $28 \%$ agree, 11 respondents representing $22 \%$ were neutral, nine respondents representing $18 \%$ disagree while no respondent strongly disagree. Also, 15 respondents representing $30 \%$ strongly agree that the period of receiving salary motivates them to work hard, 12 respondents representing $24 \%$ agree, five respondents representing $10 \%$ were neutral, 10 respondents representing $20 \%$ disagree while eight respondents representing $16 \%$ strongly disagree.

Having a good working conditions makes workers defend the hotel was a factor to organizational commitment. The analysis from the research shows that 20 respondents representing $40 \%$ strongly agree 15 respondents representing 30\% agree, while six respondents representing $12 \%$ were neutral. On the other hand, nine respondents representing $18 \%$ disagree, while no respondent for strongly disagree.

The gender of the respondents was another factor that the researcher tried to find out the relationship with organization commitment. From the analysis, it was revealed that six respondents representing $12 \%$ strongly agree that their gender makes them to continue to stay in the hotel, eight respondents representing $16 \%$ agree, while six respondents representing $12 \%$ were neutral. However, 15 respondents representing 30\% disagree while 15 respondent representing 30\% strongly disagree. Again, 15 respondents representing 30\% strongly agree that their age makes them likely to move to other company, 12 respondents representing $24 \%$ agree, five respondents representing $10 \%$ were neutral, 10 respondents representing $20 \%$ disagree while eight respondents representing $16 \%$ strongly disagree.

The result further revealed that, 20 respondents representing $40 \%$ strongly agree that they are likely to leave the hotel because of their educational level, 15 respondents representing $30 \%$ agree, six respondents representing $12 \%$ were neutral, nine respondents representing $18 \%$ disagree while no respondent for strongly disagree. On the issue of marital status of the respondents nine respondents representing $18 \%$ strongly agree that their marital status makes them still stay in their hotel, 12 respondents representing 24\% agree, eight respondents representing 16\% were neutral, and eight respondents representing 16\% disagree while 13 respondent representing $26 \%$ strongly disagree.

Table7: Relationship between Factors and Organizational Commitment

\begin{tabular}{|l|l|l|l|l|l|}
\hline Relationship & \multicolumn{1}{|c|}{ SA } & \multicolumn{1}{|c|}{ A } & \multicolumn{1}{|c|}{ N } & D & SD \\
\hline $\begin{array}{l}\text { Having the right tools at work place } \\
\text { makes me complete my work on time }\end{array}$ & $16(32.0 \%)$ & $14(28.0 \%)$ & $\begin{array}{l}11 \\
(22.0 \%)\end{array}$ & $9(18.0 \%)$ & $0(0.0 \%)$ \\
\hline $\begin{array}{l}\text { Period of receiving salary motivates } \\
\text { me to work hard }\end{array}$ & $15(30.0 \%)$ & $12(24.0 \%)$ & $5(10.0 \%)$ & $10(20.0 \%)$ & $8(16.0 \%)$ \\
\hline $\begin{array}{l}\text { Good working conditions makes me } \\
\text { defend the hotel }\end{array}$ & $20(40.0 \%)$ & $15(30.0 \%)$ & $6(12.0 \%)$ & $9(18.0 \%)$ & $0(0.0 \%)$ \\
\hline $\begin{array}{l}\text { My gender makes me to continue to } \\
\text { stay in the hotel }\end{array}$ & $6(12.0 \%)$ & $8(16.0 \%)$ & $6(12.0 \%)$ & $15(30.0 \%)$ & $15(30.0 \%)$ \\
\hline $\begin{array}{l}\text { My age makes me likely to move to } \\
\text { other company }\end{array}$ & $15(30.0 \%)$ & $12(24.0 \%)$ & $5(10.0 \%)$ & $10(20.0 \%)$ & $8(16.0 \%)$ \\
\hline $\begin{array}{l}\text { My likely to leave the hotel because } \\
\text { of my educational level }\end{array}$ & $20(40.0 \%)$ & $15(30.0 \%)$ & $6(12.0 \%)$ & $9(18.0 \%)$ & $0(0.0 \%)$ \\
\hline $\begin{array}{l}\text { My marital status makes still stay in } \\
\text { this hotel }\end{array}$ & $9(18.0 \%)$ & $12(24.0 \%)$ & $8(16.0 \%)$ & $8(16.0 \%)$ & $13(26.0 \%)$ \\
\hline
\end{tabular}

Source: Field Survey, 2017 


\section{KEY FINDINGS}

It was found out that most workers place importance to "having the right tools at work". This was because most respondents of $30 \%$ and $24 \%$ strongly agree and agree respectively that having the right tools at work place is a factor to organizational commitment. The period of receiving salary as a factor to organizational commitment revealed a balanced decision were most of them indicated a neutral decision.

The research also revealed that work relationship with Supervisor was not a significant factor to organizational commitment were $26 \%$ of the workers strongly disagree. In addition, it was found out that relationship with co-workers that exist in organization was not a factor to organizational commitment with most of the respondents strongly disagreeing. Analyses from the findings reveal that working conditions as well as working environment were significant factors to organizational commitment

Demographic Factors to organizational commitment were also examined. It was found out that $32 \%$ of the respondents strongly agree that gender was a significant factor to organizational commitment. Also, educational level of hotel workers was a factor determining organizational commitment. However, it was found out that marital status and religion status of hotel workers was not an important factor to organizational commitment.

\section{Conclusion}

This study showed that work and demographic characteristics have an effect on different dimensions of organizational commitment. Most of the obtained results of the present study are in conformity with earlier findings. Since the data were collected from a hospitality industry, replicating this study in other types of organizations would help in determining the validity and generality of present findings. Due to nature of the job in the hotels, the number of male employees was quite small as compared to their female counterparts; hence, caution must be exercised in generalizing the findings of the present study.

\section{RECOMMENDATIONS}

- It is recommended that Management of the various hotels should encourage employees to build optimistic attitude in their personality which would automatically increase their commitment. Also, the working environment and having the right tools should be the concern of hotel managers.

- Also, it is recommended that the gender and educational level of the workers in the hospitality industry be of great concern to the hotels since this has an impact on workers turnover and overall commitment.

\section{REFERENCES}

[1] Cohen A., Multiple Commitments in the Workplace: An integrative approach. Mahwah, NJ: Lawrence Erlbaum Associates, 2003

[2] Ashforth B. E., Harrison S. H., Corley K. G., Identification in Organizations: An Examination of Four Fundamental Questions. Journal of Management. Vol. 3, p.4, 2008

[3] Jena R. K., An Assessment of Demographic Factors Affecting Organizational Commitment among Shift Workers in India. Management, Vol. 20, 2015.

[4] Meyer J., Allen N., commitment in the work place, theory research and application. Human resource management review, 1, 61-89, 1997.

[5] Newstrom J. W., Organizational Behavior-Human Behavior at work. (12 ${ }^{\text {th }}$ Ed.). New York: McGraw Hill International Edition, 2007.

[6] Qureshi M. I. Saleem M. A., Basheer S., Salahuddin H., sheikh M. I., and Saadat U. R., Assessment of Selected Factors on Organizational Commitment. Gomel University Journal of Research. Vol. 8p.2, 2012.

[7] Pepra-Mensah J., Adjei L. N., and Yeboah-Appiagyei K., The Effect of Work Attitudes on Turnover Intentions in the Hotel Industry :The Case of Cape Coast and Elmina (Ghana). European Journal of Business and Management.Vol.7 p.14, 2015. 
[8] Jokivuori P., Satisfaction with HR Practices and Commitment to the Organization: Why One Size Does Not Fit All. Human Resource Management Journal. Vol.15 p.4, 2001.

[9] Cohen A., Commitment Before and After: An Evaluation and Re-Conceptualization of Organizational Commitment. Human Resource Management Review. Vol.17 p.3, 2007.

[10] Meyer J., P., and Allen N. J., Commitment in the workplace: Theory research, and application. Thousand Oaks, CA: Sage Publishing, Correlates, and Consequences. Journal of Vocational Behavior. Vol. 6 p.1, 2000.

[11] Mohamed A. R., Eman, M. A., Ahmed E., \& Shaimaa F., Organizational Commitment, Job Satisfaction and Job Performance as a mediator between Role Stressors and Turnover Intentions a Study from an Egyptian cultural perspective. The Business \& Management Review, Vol.3 p.2, 2013.

[12] Rabindarang S., Bing K. W., and Yin K. Y., The Impact of Demographic Factors on Organizational Commitment in Technical and Vocational Education. Malaysian Journal of Research, Vol. 2, 2014.

[13] Pala S., Eker F., \& Eker M., The Effects of Demographic Characteristics on Organizational Commitment and Job Satisfaction: An Empirical Study on Turkish Health Care Staff. The Journal of Industrial Relations and Human Resources, Vol. 10, 2008.

[14] Choong Y. O., Tan C. E., Keh C. G.,, Lim Y. H., \& Tan Y. T., How Demographic Factors Impact Organisational Commitment of Academic Staffs in Malaysian Private Universities: A Review and Research Agenda. International Journal of Academic Research, Vol. 4, 2012.

[15] Sikorska-Simmons E., Predictors of Organizational Commitment among Staff in Assisted Living. Gerontologist, 45 (2), pp. 196-205, 2005.

[16] Mai T. N. N. K. N., \& Nguyen P. V., Factors Affecting Employees' Organizational Commitment-A Study of Banking Staff in Ho Chi Minh City, Vietnam. Journal of Advanced Management Science. Vol. 2(1), 2014.

[17] Bolgatanga Municipal Assembly, The Composite Budget of the Bolgatanga Municipal Assembly, Ghana for the 2014 Fiscal Year, 2014.

Citation: John, Adansi et al. "Assessing the Factors Affecting Workers Commitment in Hotel Industry in the Bolgatanga Municipality of Ghana." International Journal of Research in Tourism and Hospitality (IJRTH), vol 3, no. 3, 2017, pp. 7-15. doi:http://dx.doi.org/10.20431/2455-0043.0303002.

Copyright: (0) 2017 Authors. This is an open-access article distributed under the terms of the Creative Commons Attribution License, which permits unrestricted use, distribution, and reproduction in any medium, provided the original author and source are credited. 